\title{
The Missing Element in the Republican Revival
}

\author{
Jonathan R. Macey†
}

Cass Sunstein's article, "Beyond the Republican Revival"1 captures with enormous clarity and elegance the task of the modern republicans, which is to specify and defend a conception of public life in which the power of government is unleashed to do good. At the core of this conception is the "republican belief in the subordination of private interests to the public good," which provides the justification for unleashing the power of government. What is missing from Sunstein's conception of government is the pluralist belief that the desire for private economic gain and the necessity of political survival often drive self-interest into political life and obscure the intentions of even the most well-meaning political actors. In my view, Sunstein's appeal to civic virtue does not represent a new perspective on political ordering, so much as a new, aspirational perspective on human nature - one that was not shared by the framers and does not reflect reality.

In other words, what is missing from the republican revival is an appreciation of the frightening power of man to subvert the offices of government for what can only be described as evil ends. ${ }^{3}$ It is this gap that deprives pure republicanism of any prospect of serving as a viable constitutional theory. Thus, my argument is not that Sunstein's aspirational appeal to civic virtue is always wrong; my claim is only that it is not always right. And constitutional rules become most important when compassion and civic virtue are on the wane, not when they are on the rise.

This comment consists of two sections, each of which will explore a different aspect of what I take to be the missing element in Sunstein's republican vision. In the first section, I will look at the framing of the Constitution to show that Sunstein's depiction of pluralism differs significantly from the pluralist conception of the framers. Sunstein's ahistorical depiction of pluralism enables him to draw a sharp contrast between plu-

† Professor of Law, Cornell University. A.B. 1977, Harvard University; J.D. 1982, Yale Law School.

1. Sunstein, Beyond the Republican Revival, 97 YALE L.J. 1539 (1988).

2. Id. at 1540 .

3. For pluralists, the tendency to do evil is usually attributable to self-interest, although evil results sometimes from other sources, such as "crackpot racial theories." See Cameron, The Lie on the Soul, N.Y. Rev. Books, Mar. 17, 1988, at 3. 
ralism and republicanism. I hope to show in section I that the framers' pluralist vision is still quite robust, and in section II that the distinction Sunstein draws between pluralism and republicanism all but disappears when one sees pluralism as the framers themselves saw it.

Section I points out that the framers foresaw that narrow partisanship and other-regarding republicanism would take turns at the center stage of American political life. In light of this prediction, the framers designed a constitution to cope with those times when narrow self-interest would dominate the political scene. The essence of the framers' genius was that they were able, for the first time in history, to design a constitution that contemplated the awesome range of human capability. Their plan was to hope for republicanism but to gird the republic for an onslaught of pluralism. Indeed, if the framers can be faulted, it is for failing to predict the ever-increasing heterogeneity of the polity, which gives the pluralist vision a concomitantly ever-increasing hold on the American political scene.

Section II of this essay considers the policy implications of Sunstein's republicanism. The policy goal of Sunstein's republicanism is somehow to resolve the disputes that arise in the political arena in a way that is generally acceptable. ${ }^{4}$ The way to achieve this is through deliberation, a process that allows the various parties to a dispute to see the matter from the perspective of their adversaries. According to Sunstein, this new perspective leads to empathy, which, in turn, fosters accommodation and compromise. But in the real world, most of what government does is effectuate wealth transfers from the politically weak to the politically powerful. In this context, deliberation is more likely to lead to discord than to altered preferences.

In general, Sunstein's demand that legislators deliberate before acting will make it more costly for interest groups to achieve their goals. As such, his policy prescriptions are no different from those that a utilitarian pluralist would make, because they reduce the ability of interest groups to control the political process. Section II advances this argument and shows that Sunstein's policy prescriptions do not in any way enable us to distinguish his modern republicanism from my interest group pluralism. Thus, at the end of the day, the sole distinguishing feature of Sunstein's republicanism is a faith in human virtue that the framers did not themselves embrace, and which does not correspond to reality.

\section{What the Framers Were Doing}

Sunstein declares that "[i]t is no longer possible to see a Lockean consensus in the founding period, or to treat the framers as modern pluralists believing that self-interest is the inevitable motivating force behind politi-

\footnotetext{
4. Sunstein, supra note 1 , at 1547-48.
} 
cal behavior [because] [r]epublican thought played a central role in the framing period ...." Sunstein later retreats from this rather sweeping piece of revisionist history, recognizing that "one can find a rejection of central features of traditional republicanism" during the period of the framing of the Constitution. ${ }^{6}$ But Sunstein clings to the notion that "elements of republican thought [as opposed to "republican thought"] played an important [as opposed to "central"] role in the framing period."

Elements of republican thought did play a role in the framing period. Most notably, as Sunstein observes, the electoral college and the selection of senators by state legislatures were designed to insure that only the most distinguished men in the country could assume public responsibility. What is immediately apparent, of course, is that the very elements of republicanism that Sunstein identifies invariably have been jettisoned as the country has grown and become more diverse and less elitist. Senators are not chosen by state legislators, and the electoral college, which convenes by telephone quadrennially, has assumed a far more passive role than was envisioned by those who wanted it to become a fully deliberative body.

These concrete examples of the modern rejection of the framers' republican aspirations do not begin to scratch the surface. The increasing political power of special interest groups conspires with the increasingly heterogeneous nature of society to make the more subtle, aspirational elements of the framers' republican vision appear no more than a distant dream. Through a gradual process of political evolution and adaptation, we have come to accept and even value diversity and dissent, while we no longer see such republican "virtues" as homogeneity and cooperation as particularly valuable goals to which to aspire. ${ }^{7}$ The melting pot of republicanism has given way to the rainbow coalition of pluralism. If strands of both republicanism and pluralism co-existed at the time of the framing, it is the pluralist strands that have survived and flourished.

From the fact that early Congresses rejected a constitutional amendment that would entitle constituents to instruct their representatives how to vote, Sunstein infers that ' $[t]$ he framers' conception of representation .... incorporated the traditional republican faith in the value of virtue and deliberation in politics."

5. Id. at 1540 .

6. Id. at 1558 (discussing skepticism of Madison and Hamilton about republican thought).

7. History has shown the value of distrusting the state and of valuing dissent and diversity. In explaining the help given by various Italian citizens to Italian Jews during the Holocaust, Adrian Lyttelton points out that a lot of credit is due to the lack of republican virtue in Italian society: Jewish survival would be hard to explain without taking into account certain features of Italian culture. The Italians did not trust the state. They showed an attitude of disobedience and skepticism toward the law and the duties of the citizen. They frequently acted at odds with their expressed beliefs, incurring the charge of cynicism. They lacked a true 'civic culture'. . . . The Holocaust casts a dark light on previously received notions of civic virtue.

Lyttelton, La Forza del Destino, N.Y. Rev. Books, Mar. 31, 1988, at 3, 8.

8. Sunstein, supra note 1 , at 1560 . 
depiction of the "Federalist desire for a high-toned government filled with better sorts of people"' better captures the true motives of the framers, Sunstein is correct that the framers saw a role for deliberation in some aspects of lawmaking. It was not the role that Sunstein has in mind, however. In fact, it was a role fully consonant with the framers' pluralist vision.

The framers considered it important to foster deliberation and circumspection in order to diminish the efficacy of interest groups by making it more difficult for them to pass laws. As Madison observed in The Federalist No. 62, "the facility and excess of lawmaking seem to be the diseases to which our governments are most liable . . ."10 The solution - raising the costs of passing laws - was not without a cost of its own, but the framers believed that the "injury which may possibly be done by defeating a few good laws will be amply compensated by the advantage of preventing a number of bad ones."11

In addition to raising the costs of passing statutes, the requirement of deliberation forces lawmakers to defend their positions in public. This publicity raises the political costs to legislators of taking positions that are not in the interests of their constituents. In the absence of such publicity, interest groups might exert even more control over the outcomes of the political process, since lawmakers could serve the interests of such groups without informing their constituents of their actions. ${ }^{12}$

A final pluralist reason for encouraging deliberation is to diminish the incidence of incoherence, irrationality, and inconsistency that attends all collective decisionmaking, particularly one in which the decisionmakers represent opposing constituencies and interest groups. ${ }^{13}$ The framers were alert to the propensity for irrationality in collective action, later formally explained by Kenneth Arrow, that had led to "chaos under the Articles of Confederation"14 and to "spectacles of turbulence and contention"15 in earlier democracies.

These arguments in favor of deliberation in the lawmaking process, all of which are based on a decidedly pluralist conception of political theory, go unacknowledged by Sunstein. Instead, Sunstein believes that deliberation will foster virtue and wisdom among our leaders, who therefore will act in our best interests, even when we are unable to discern properly for

9. G. Wood, The Greation of The American Republic, 1776-1787, at 562 (1969).

10. The Federalist No. 62, at 378 (J. Madison) (C. Rossiter ed. 1961).

11. The Federalist No. 73, at 444 (A. Hamilton) (C. Rossiter ed. 1961).

12. See Macey, Promoting Public-Regarding Legislation Through Statutory Interpretation: An Interest-Group Model, 86 Colum. L. REv. 223, 233, 252-56 (1986) (arguing that political cost of passing statutes oriented towards special-interest groups is higher when true purposes of statute are understood).

13. Mayton, The Possibilities of Collective Choice: Arrow's Theorem, Article I, and the Delegation of Legislative Power to Administrative Agencies, 1986 Duke L.J. 948, 953.

14. Id. at 953 .

15. The Federalist No. 10, at 81 (J. Madison) (C. Rossiter ed. 1961). 
ourselves what those interests are. ${ }^{16} \mathrm{I}$ do not take this to be the motivating principle that drove the framers' political science.

For example, it is difficult to reconcile Sunstein's idea that "The Federalist No. 10 emphasized the capacity of a large republic to obtain publicspirited representatives, operating above the fray of constituent pressures ${ }^{17}$ with the decidedly pluralistic tenor of the text itself:

It is in vain to say that enlightened statesmen will be able to adjust these clashing interests and render them all subservient to the public good. Enlightened statesmen will not always be at the helm. Nor, in many cases, can such an adjustment be made at all without taking into view indirect and remote considerations, which will rarely prevail over the immediate interest which one party may find in disregarding the rights of another or the good of the whole. ${ }^{18}$

While Sunstein is correct that Madison emphasized the advantages of a large republic over a small republic, he did so for a pluralistic reason. Madison was convinced that a large republic likely would be successful in controlling faction, and this was his principle concern. I believe Neil Komesar captured perfectly the spirit of The Federalist No. 10 when he observed that "Madison may have hoped for the ascendancy of noble spirits, but he apparently expected and planned for far more mortal ones."19

In other words, Sunstein correctly points to the framers' conception of the individual as a "civic and active being, directly participating in the respublica according to his measure." ${ }^{20}$ But he fails to explore the pluralist implications of the "historical pessimism in American thought at its most utopian, which stems from the confrontation of virtue and commerce."21 J.G.A. Pocock, perhaps America's foremost writer on the republican tradition, has traced republicanism from Florentine Italy to early America and found that, in America, it was recognized that virtue in government was constantly threatened with corruption by modernity. ${ }^{22}$

Seen from this perspective, Sunstein's occasional efforts to refute the

16. One must wonder, incidentally, why Sunstein is so certain that deliberation will lead to virtue. Deliberation may lead to rationality, but if the deliberators do not begin their conclaves with a predisposition towards virtue, it is not obvious why the discussion necessarily will lead them in this direction.

17. Sunstein, supra note 1 , at 1559.

18. The FEDERalist No. 10, at 80 (J. Madison) (C. Rossiter ed. 1961); see also S. Shiffrin, The First Amendment and Romance (1988) (unpublished manuscript) ("By a curious sleight of hand, Professor Sunstein associates Madison's Federalist 10 (with its strong Burkean notions) with Republicanism-this despite the emphasis of Republicans on participatory localism and despite the desire of many Republicans to bind representatives to follow the expressed will of the people.").

19. Komesar, Paths of Influence - Beard Revisited, 56 GEo. WASH. L. REv. 124, 132 (1987) (emphasis in original).

20. I. Howe, The american Newness: Culture and Politics in the Age of Emerson 54 (1986) (quoting J.G.A. Pocock, The Machiavellian Moment: Florentine Political Thought and the Atlantic Republican Tradition 523 (1975)).

21. Id.

22. J.G.A. Pocock, supra note 20, at 509. 
pluralist conception of political life seem sorely misplaced. ${ }^{23}$ Contrary to Sunstein's assertion, the pluralist vision that interest-group struggle is the hallmark of the political arena is not a goal to aspire to, but rather a condition to be avoided by designing a constitution that would make it more difficult for interest groups to dominate the political landscape. ${ }^{24}$ As my colleague Steve Shiffrin observes, Sunstein casts republicanism "against a species of pluralism that did not exist in the eighteenth century."2s

To the pluralist, the same self-interest that is assumed to guide commercial transactions in the private sector also guides the transactions that we observe in the political sector. The difference is that, while this selfinterested behavior generally leads to efficient, socially desirable, valuemaximizing outcomes in the private sector, it leads to what Judge Richard Posner (a noted pluralist) accurately has described as "amorally redistributive" wealth transfers in the public sector. ${ }^{26}$

Sunstein, then, is correct to link the pluralist approach to interest group theories of politics, ${ }^{27}$ but he is wrong to suggest that all those who see the pluralist conception as an accurate portrayal of political life view this portrayal as a good thing. ${ }^{28}$ Rather, partisan politics is a fact of life that stems not only from narrow self-interest, but also from the fact that allegiances to particular sub-groups, such as religions, ethnic groups, or trade and professional organizations, often trump allegiances to the nation as a whole. Often (though not always) these allegiances lead to political outcomes that are not in the public interest. Thus, Sunstein's claim that "[i]t is no longer possible to see a Lockean consensus in the founding period, or to treat the framers as modern pluralists believing that self-interest is the inevitable motivating force behind political behavior"29 is problematic. The framers rejected the rather eccentric strand of modern interest group pluralism that claims that aggregating preferences through interest group struggles in the political process produces generally desirable outcomes. In contrast, the framers' (somewhat mistaken) view was that "a country large enough, and an economy vibrant enough, to stimulate a broad range

23. See, e.g., Sunstein, supra note 1, at 1542-47.

24. See Macey, Competing Economic Views of the Constitution, 56 Geo. Wash. L. Rev. 50 (1987); Macey, Transaction Costs and the Normative Elements of the Public Choice Model: An Application to Constitutional Theory, 74 VA. L. REV. 471 (1988).

25. S. Shiffrin, supra note 18 (emphasis in original).

26. Posner, Economics, Politics, and the Reading of Statutes and the Constitution, 49 U. CHI. L. REv. 263,268 (1982).

27. Sunstein, supra note 1 , at 1542 n.9.

28. Those pluralists Sunstein cites argue that pluralism is a good thing because it generates governmental outcomes that are consistent with citizen preferences. See sources cited id. This is incorrect. Rational ignorance, free rider problems, and other collective action problems conspire to give special interest groups disproportionate influence over political outcomes. Thus, many interest group-oriented pluralists reject the notion that pluralism leads to an accurate aggregation of citizen preferences in the political sphere. See Macey, supra note 12, at 227-33.

29. Sunstein, supra note 1 , at 1540 . 
of differentiated interests would produce a somewhat depoliticized citizenry." ${ }^{\text {Bo }}$ But more importantly, they did not reject the more fundamental claim that interest groups needed to be tamed through constitutional ordering. The way to achieve this, however, was not to pray for enlightened statesmen, but to raise the costs of governmental action ${ }^{31}$ and to provide public officials with incentives to act in the public interest. ${ }^{\mathbf{2 2}}$

Thus, in sum, my response to Sunstein is threefold. First, I agree it often will be the case that individuals will voluntarily subsume their personal preferences to the preferences of a group. Second, I dispute Sunstein's assertion that it is deliberation that leads individuals to agree to act altruistically. Finally, virtually every person in society belongs to a complex web of groups and coalitions, each of which has legitimate claims to the interests of that individual. As a descriptive matter, it is to this web of groups and coalitions rather than to the nation as a whole that an individual's primary allegiance belongs during times of politics as usual.

Thus, in pluralist America, it is simply not realistic to think that an individual will put the interests of the community ahead of his own because, in all likelihood, the individual has pre-existing commitments to a host of other entities, such as religious groups, ethnic groups, and labor and professional organizations. The allegiance to any one of these groups is likely to trump any commitment to as amorphous a concept as "the community." The question, then, is not, as Sunstein suggests, whether one values community; rather, the questions are which community among the several to which one belongs does one value most at any given time, and how does one resolve differences when there is conflict among the various communities with which one identifies.

The pluralist conception embraced by the framers leads to a radically different view of governmental action than the aspirational conception of republicanism that Sunstein describes. Where Sunstein's republicanism would lead a pluralist to empower interest groups, the framers' pluralism leads to attempts to mitigate the influence of such groups. In fact, as the following section shows, the framers' conception of pluralism contains policy implications that mirror Sunstein's republican prescriptions, and thereby rob Sunstein's republicanism of any claim to supplementing the policy implications of the framers' pluralist vision. In the end, all we are left with to distinguish the framers' pluralism from Sunstein's republicanism is the decidedly republican idea of civic virtue, which is a concept flatly rejected by the framers as a sufficient theoretical predicate for the new constitution.

30. Malbin, Factions and Incentives in Congress, PuB. INTERest, Winter 1987, at 91-92.

31. See Macey, Transaction Costs and the Normative Elements of the Public Choice Model: An Application to Constitutional Theory, supra note 24, at 493-505.

32. See Malbin, supra note 30 , at 92 . 


\section{Republicanism as Policy}

Sunstein's claim that the republican perspective is entitled to weight in approaching modern political decisions gives his ideas a policy punch. So, for example, Sunstein would permit new laws to be adopted only "after multiple points of view have been consulted and (to the extent possible) genuinely understood." $33 \mathrm{He}$ also would require that public-regarding justifications be offered for such laws. ${ }^{34}$

But if these are the normative implications of Sunstein's analysis, his disagreement with pluralism is more imagined than real. Sunstein does not think that narrow-minded interest group politics should dominate the political sphere. But no pluralist who understands the calamitous societal implications that would accompany such interest group domination ${ }^{35}$ would disagree. Disagreement arises only over the difficult, but narrower question of how to deal with the problem of non-public-regarding lawmaking. To the extent that Sunstein's solution is to appeal to civic virtue, his political vision differs from all brands of pluralism. A pluralist's solution to the problem of bad laws is to design a system of government that reduces the power of government by raising the costs of passing laws that transfer wealth and economic power from the politically weak to the politically powerful.

At the end of his article, Sunstein draws several implications from his republican perspective on government, which I will now consider seriatum. While I find myself in complete agreement with the substance of many of his suggestions, my agreement stems less from being persuaded that republicanism is a useful approach to policy issues than from the fact that his suggestions will reduce the efficacy of interest groups and therefore also are consistent with my own pluralistic understanding of politics.

For example, Sunstein advocates a republican gloss on the First Amendment that would validate campaign finance regulation.$^{36}$ From a pluralist perspective, the merits of this suggestion lie in its prospect for lessening the influence of interest groups whose expenditures cause distortions in the campaign process. Sunstein argues for validating campaign finance regulation on the grounds that curbing expenditures and donations would improve the deliberative process. ${ }^{37}$

The pluralist argument for regulation in this area, while not without problems of its own, ${ }^{38}$ might provide a better justification for regulating

33. Sunstein, supra note 1 , at 1575 .

34. Id.

35. Mancur Olson's work provides the most dismal-and the most complete-expression of the implications of unfettered interest group political agitation. M. OLSON, THE RISE AND DECLINE of Nations (1982).

36. Sunstein, supra note 1 , at $1576-78$.

37. Id. at 1577.

38. From the pluralist perspective, the problem with campaign finance regulation is that it is unlikely to reduce the influence of interest groups. It is more likely that campaign finance regulation 
campaign finances than the republican argument. Indeed, Sunstein's suggestion that such finances be regulated could hamper rather than facilitate the deliberative process among voters. Limitations on campaign contributions and expenditures would reduce the effectiveness of certain groups, but would increase the effectiveness of others, such as incumbents, who have low cost access to the ear of the public. This skewing of the advantage in favor of incumbents might retard rather than enhance the quality of the deliberative process. In a world of incumbents, campaign finance regulation simply distorts the current advantage that incumbents hold by making dialogue and deliberation less important to their political survival.

Sunstein's new republicanism revives federalism as a valuable mechanism for providing "outlets for self-determination in the public and private spheres." ${ }^{39}$ Federalism, of course, has long been a favorite ally of pluralists, because strong and responsive local governments and other intermediate organizations decrease the opportunities for interest group politics by focusing the costs of such activity on the groups best equipped to combat it. ${ }^{40}$

Sunstein also applauds the fact that courts review statutes for "rationality" in a variety of contexts because such rationality review "is best understood as a requirement of deliberation by public officials." 41 But rationality review does not require deliberation, as Sunstein suggests, because judges do not look at whether the legislature has articulated a justification for their actions when they engage in rationality review. Rather, courts engage in an objective inquiry to determine whether a rational basis can be said to exist for the statute in question. If the legislature did not supply one, the court often will make one up if it can. By contrast, the pluralist would insist on a rational basis, not to force the legislature to contribute background pabulum every time it enacts a statute, but because statutes without a rational basis generally are enacted to serve the ends of special interests. ${ }^{42}$ This was also the view of the framers, who viewed the process of statutory interpretation by independent judges as a means for safeguarding the interests of individual citizens against interest group tyranny. ${ }^{43}$

merely shifts the advantage from interest groups with more money to interest groups with greater organizational abilities. Thus, from a pluralist perspective, one argues for campaign finance regulation if one favors the interest groups that will prevail under such regulations over those groups that will prevail in their absence. In addition, because such laws are passed by incumbents, they are particularly likely to benefit incumbents. Therefore, it is sensible, even from a republican perspective, to view campaign finance laws with suspicion.

39. Sunstein, supra note 1 , at 1578 .

40. Epstein, Self-Interest and the Constitution, CAto PoL'y REP., Jan.-Feb. 1988, at 1, 10; McConnell, Federalism: Evaluating the Founders' Design, 54 U. CHI. L. REv. 1484 (1987); Macey, Competing Economic Views of the Constitution, supra note 24.

41. Sunstein, supra note 1 , at 1579.

42. Sunstein, Naked Preferences and the Constitution, 84 Colum. L. REv. 1689, 1695-1705 (1984).

43. See The Federalist No. 78, at 470 (A. Hamilton) (C. Rossiter ed. 1961): 
Sunstein's claim that the republican tradition furnishes a new lens through which to view the lesson of the Lochner era is quite compelling. His idea is that the crucial event in the Lochner era was not the change in the institutional role of the judiciary in overseeing the political process, but rather in the ultimate rejection of the idea that "fundamental" rights are natural and pre-political and the embrace of a conception of rights as a purely political manifestation of " $a$ well-functioning deliberative process." 44

But once again, the pluralist perspective on the Lochner era controversy differs little from Sunstein's republican account. To the pluralist, the question of whether rights are "pre-political" is purely academic. The crucial point is that interests are pre-political, and that the legislature is the proper arena for battles among these various interests. The lesson of Lochner is that political as well as economic power plays a fundamental role in allocating economic resources in a pluralist society, because interest group politics in the political sphere affect the distribution of resources in the private sphere.

Sunstein also argues for proportional representation from a republican perspective. I will not dwell on this issue since Sunstein himself makes the point that proportional representation might be justified on both pluralist and republican grounds. ${ }^{45}$ Suffice it to say that the pluralist would not consider representation valuable at all, unless the group represented was given the power to affect political outcomes. Sunstein, by contrast, believes that even powerless groups will be able to affect political outcomes if the system is designed in such a way that the voices of minorities will be heard. To the republican, the danger of proportional representation is that it will ratify, perpetuate, and encourage interest group struggle. ${ }^{16}$ But the danger of proportional representation in the eyes of the pluralist is virtually identical - that it will heighten the power and increase the efficacy of interest groups, whose goal is the self-interested pursuit of wealth transfers in the political process.

Finally, Sunstein argues at length for a new approach to statutory construction - one that would reinforce republican theories of politics. ${ }^{47} \mathrm{~A}$ pluralist, such as myself, who takes the view that courts should not seek out and enforce the hidden "deals" made among interest groups and politicians, would agree fully with Sunstein's suggestion that the canons of

[I]t is not with a view to infractions of the Constitution only that the independence of the judges may be an essential safeguard against the effects of occasional ill humors in the society. These sometimes extend no farther than to the injury of the private rights of particular classes of citizens, by unjust and partial laws.

44. Sunstein, supra note 1, at $\mathbf{1 5 8 0}$. One must wonder if Sunstein would consider an appropriate test of a political process to be whether the process generates the fundamental rights that Sunstein values most highly. This appears to be the case. Therefore, Sunstein's argument appears circular.

45. Id. at 1586 .

46. Id. at 1587 .

47. Id. at 1581-85. 
statutory construction should be used so as to force Congress to be honest about what it does. ${ }^{48}$ These canons can be justified from a pluralist perspective on the ground that they raise the costs to politicans of forging non-public-regarding "deals" with special interest groups at least as easily as they can be justified by the republican argument that they enhance the quality of the deliberative process. ${ }^{48}$

Thus, it appears that the implications of Sunstein's republicanism differ little from the implications of a pluralist vision that recognizes the destructive possibilities of unfettered factionalism. But one should not infer from this that Sunstein's republicanism closely resembles my form of pluralism. The two approaches to political theory differ enormously in the power each is willing to cede to the sovereign. The republican's only limitation on the power of the sovereign is the requirement that it deliberate before acting. The pluralist places little or no faith in the outcomes generated by a factionalized political process, whether or not it is (or appears to be) "deliberative" in nature. ${ }^{30}$

The reason pluralism appears the more attractive approach is that it does not harbor the illusion that the avarice and self-interest that marks government policymaking in a pluralist society can be tamed by placing a higher value on deliberation. For the pluralist, the problems that Sunstein identifies can only be curbed by limiting the power of the sovereign to benefit special interests.

\section{ConClusion}

The difference between pluralists and republicans lies in their disagreement over the nature of man. Republicans focus their attention on man's enormous capacity to do good. Their vision is correct, but it is only partially correct. Pluralists focus on the capacity of man to do evil, a capacity that often is fueled by self-interest.

One need not be a republican to agree with Sunstein that self-interest is an insufficient basis for justifying political outcomes. One does not even need to be a republican to believe that rights are not pre-political. Quite the contrary: anyone who has observed the outcomes generated by the Supreme Court over the last fifty years in cases dealing with property rights must realize that such rights are pre-political only in the most academic sense. What is pre-political to the pluralist are not rights, but interests. The goal of political theory is to design ways to channel those interests towards the public good.

This, really, is the difference between Sunstein and myself. Where Sun-

48. Id. at $1582-83$.

49. See Macey, supra note 12 , at 264-66.

50. Deliberation is, of course, valuable to the extent that it provides people with information about the true nature of their own preferences and about the implications of various events on those preferences. But this, of course, is not the sense in which Sunstein invokes the term. 
stein looks to "republican aspiration to counteract republican practice," the pluralist looks at pluralist political theory - particularly the modern economic theory of regulation - to counteract both pluralist practice as well as republican practice. Two of the most salient lessons of history are the mixed success of governmental efforts to do good on the one hand and the awesome success of the government when it turns its hand to hatred and destruction on the other. ${ }^{52}$ It is in light of these intractable lessons that Sunstein's reliance on civic virtue assumes an ominous dimension.

51. Sunstein, supra note 1 , at 1581 .

52. See generally P. Johnson, MOdern Times: The World From the TWEnties to the EIGHTIES (1983). 